\title{
The Future Challenge: Water Demand Forecasting
}

\author{
Anggi Nidya Sari \\ Politeknik Negeri Sriwijaya \\ * e-mail: angginidya@polsri.a c.id
}

\begin{abstract}
Palembang has abundant water sources; the city of Palembang is traversed by one of the longest rivers in Indonesia, the Musi River. However, population growth is increasing over time, as is the need for clean water. Projections of the amount of clean water demand in the future are needed; apart from anticipating water shortages, water demand projections are required to construct clean water facilities and infrastructure. This research was conducted using statistical calculations to calculate the population in the next ten years. The population of Palembang in 2030 is projected to increase to1,898,221 inhabitants. The results of this population projection are used in calculating the total water demand in 2030 . The total water demand is obtained from the calculation of domestic, non-domestic, fire hydrant, and water loss needs. In 2030, the total amount of water needed is $6,816 \mathrm{~L} /$ second.
\end{abstract}

Keywords: Forecasting, Water Demand, Water Need, Population.

(9) Licensees may copy, distribute, display and perform the work and make derivative works and remixes based on it only if they give the author or licensor the credits (attribution) in the manner specified by these. Licensees may copy, distribute, display, and perform the work and make derivative works and remixes based on it only for non-commercial purposes.

\section{INTRODUCTION}

Water is one of the important components in life. All living things on this earth need water to survive. Plants, animals, and humans need water in their daily life. In particular, they need water for drinking, washing, cooking, transportation, etc. (Langi \& Mangangka, 2015). Earth contains a lot of water, which consists of rivers, seas, lakes, etc. However, only $3 \%$ of freshwater that can be used comes from rivers, lakes, and groundwater(June \& Goals, 2018).

The life of urban communities is very dynamic, resulting in the need for water to be essential (Nugraha Sadeli Utama, 2019). In general, the need for clean water increases every year, while water availability is increasingly limited(Afrianto, 2015). the catchment area is getting narrower over time, displaced by the development and exploitation of natural water sources that do not pay attention to the environment around the water source (Suheri et al., 2019).

Palembang City is one of the most densely populated Metropolitan cities in Indonesia. The area of the city of Palembang is $400.61 \mathrm{~km} 2$, with a population of 1.6 million people by 2020 (Central Statistics Agency of South Sumatra). The population growth continues to increase every year the amount of water needed. Palembang City is one of the cities that has abundant water resources because this city is traversed by one of the longest rivers in Indonesia, namely the Musi River. But, this great water is not followed by good water quality(Suryani, 2016). Industrial activities such as mining, plantation, agriculture, and household activities in this river have resulted in a decrease in water quality, which is exposure to heavy metals such as mercury (Heru Setiawan, 2014). Household, industrial and agricultural activities result in waste that cannot be 
appropriately treated to impact environmental quality degradation(Suriawiria, 1996). Water degradation is the impact of untreated waste. The waste is disposed of directly into the river body uncontrollably. Many developments along the river have also resulted in a reduced carrying capacity of the river against pollutants(Kospa \& Rahmadi, 2019). This has resulted in a reduced amount of water in Palembang City that can be utilized.

Based on the existing problems, projections of the amount of water demand in the future are needed. The prediction of the amount of water demand in the future is also needed for the construction of better clean water facilities and infrastructure capable of serving the community equally.

\section{METHODS}

Water is one of the important components in the life of living things, especially humans. Water needs are unlimited and sustainable needs. The increase in population automatically increases water demand. However, rising in demand was not matched by an enlarge in service capabilities (Langi \& Mangangka, 2015). For an increase in the amount of water needed to be balanced within servants and projection data. Hence, the facilities and infrastructure for water needs can be immediately built to improve services.

The amount of water demand is the total amount of water needed for domestic and nondomestic needs (household, educational facilities, industrial facilities, religious facilities, and others). Domestic and nondomestic water needs are a priority (Deny, 2010).

\section{Prediction of Population Number}

The increase of the population also escalation the amount of water needed.

There are three methods commonly used to calculate population predictions:

\section{a. Arithmetic Method}

This method uses the assumption that the population growth rate is constant each year. The equation is as follows:

$P_{n}=P_{o}+\left(K_{a} \cdot X\right)$
$K_{a}=\frac{P_{o}-P_{t}}{t}$

Where :

$\mathrm{Pn}=$ total population $\mathrm{n}$ in the coming year

Po $=$ Total population at the beginning of the data year

$\mathrm{Pt}=$ total population at the end of the data year

$\mathrm{X}=$ Time interval (year from year $\mathrm{n}$ - last year)

$\mathrm{t}=$ Data year time interval $(\mathrm{n}-1)$

\section{b. Geometry Methods}

This method assumes that population development automatically doubles with population increase. In this method, the possibility of downward development is not considered. The equation is as follows:

$Y n=P_{t}(1+r)^{n}$

$r=\left(\frac{P_{t}}{P_{o}}\right)^{\left(\frac{1}{t}\right)}-1$

Where :

$\mathrm{Pn}=$ total population in the next $\mathrm{n}$ years

Po $=$ Total population at the beginning of the data year

$\mathrm{Pt}=$ total population at the end of the data year $\mathrm{n}=$ number of projection years

$r=$ The ratio of average population increase per year

$\mathrm{t}=$ Data year time interval $(\mathrm{n}-1)$

\section{c. Least Square Method}

This method is used for areas with a linear trend in population growth, although population growth does not always increase. The equation is as follows:

$$
\begin{aligned}
& Y n=a+b \cdot X \\
& a=\frac{\left(\sum Y \cdot \sum X^{2}\right)-\left(\sum X \cdot \sum X Y\right)}{\left(n \cdot \sum X^{2}\right)-\left(\sum X\right)^{2}} \\
& b=\frac{\left(n \cdot \sum X Y\right)-\left(\sum X \cdot \sum Y\right)}{\left(n \cdot \sum X^{2}\right)-\left(\sum X\right)^{2}}
\end{aligned}
$$

Where :

$\mathrm{Yn}=$ Total population in the next $\mathrm{n}$ years

$\mathrm{a}, \mathrm{b}=$ Constants

$\mathrm{X}=$ Year increment

$\mathrm{n}=$ amount of data

\section{Water Supply Standards}

There are two types of standards for clean water needs, namely (DPU, Dirjen Cipta Karya):

\section{a. Domestic Water Supply Standards}


Domestic water supply standards are obtained from the number of domestic users, which can be seen from population data. Standard domestic needs include drinking, bathing, cooking, etc.

Domestic water demand based on city size can be seen in the table below:

Table 1. Water Needs Base on City Size

\begin{tabular}{ccc}
\hline Category & City Size & $\begin{array}{c}\text { Needs } \\
\text { Water / Lt / } \\
\text { person / day }\end{array}$ \\
\hline I & Metropolitan & 190 \\
\hline II & Big city & 130 \\
\hline III & Medium City & 120 \\
\hline IV & Small town & 90 \\
\hline V & District City & 75 \\
\hline VI & Rural & 60 \\
\hline
\end{tabular}

b. Non-Domestic Water Supply Standards

Domestic water supply standards are obtained through non-domestic consumers, consisting of offices, health, industrial, commercial, public, etc.

Non-domestic water needs based on planning criteria at the Public Works Office can be seen in the table below:

Table 2. Non-Domestic Water Needs for Cities Category I, II, III, IV

\begin{tabular}{|c|c|c|}
\hline SECTOR & SCORE & UNIT \\
\hline School & 10 & lt / student / day \\
\hline Hospital & 200 & lt / bed / day \\
\hline Public health center & 2000 & lt / unit / day \\
\hline Mosque & 3000 & lt / unit / day \\
\hline Office & 10 & $\begin{array}{l}\text { lt / employee / } \\
\text { day }\end{array}$ \\
\hline Market & 12000 & lt / hectare / day \\
\hline Hotel & 150 & lt / bed / day \\
\hline Restaurant & 100 & lt / seat / day \\
\hline Military Compl & 60 & lt / person / day \\
\hline Industrial area & $0.2-0.8$ & 1t/second/day \\
\hline Tourism Area & $0.1-0.3$ & 1t/second/day \\
\hline $\begin{array}{l}\text { Table 3. Non-Dom } \\
\text { Category V (Village) }\end{array}$ & 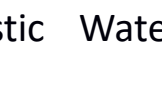 & tivecus \\
\hline SECTOR & SCORE & UNIT \\
\hline School & 5 & lt / student / day \\
\hline Hospital & 200 & lt / bed / day \\
\hline Public health ce & 1200 & lt / unit / day \\
\hline Mosque & 3000 & lt / unit / day \\
\hline Prayer room & 2000 & lt / unit / day \\
\hline Market & 12000 & lt / hectare / day \\
\hline $\begin{array}{l}\text { Commercial } \\
\text { Industrial }\end{array}$ & 10 & lt / day \\
\hline
\end{tabular}

Table 4. Non-Domestic Water Needs for Other Categories

\begin{tabular}{|c|c|c|}
\hline SECTOR & SCORE & UNIT \\
\hline Airfield & 10 & lt / person / sec \\
\hline Port & 50 & lt / person / sec \\
\hline $\begin{array}{l}\text { Train Station and } \\
\text { Bus Terminal }\end{array}$ & 10 & lt / person / sec \\
\hline Industrial area & 0.75 & lt / sec / hectare \\
\hline
\end{tabular}

\section{RESULTS AND DISCUSSION}

\section{Data On The Number Of Populations Of Palembang City 2011-2020}

Data on Palembang's population was obtained from the BPS (Central Statistics Agency) of Palembang City in 2020. This data is used to estimate population growth and the number of clean water needs of Palembang City in 2021-2030. Population data for 20112020 is presented in the table below.

Table 5. Total Population of Palembang City, 2011-2020

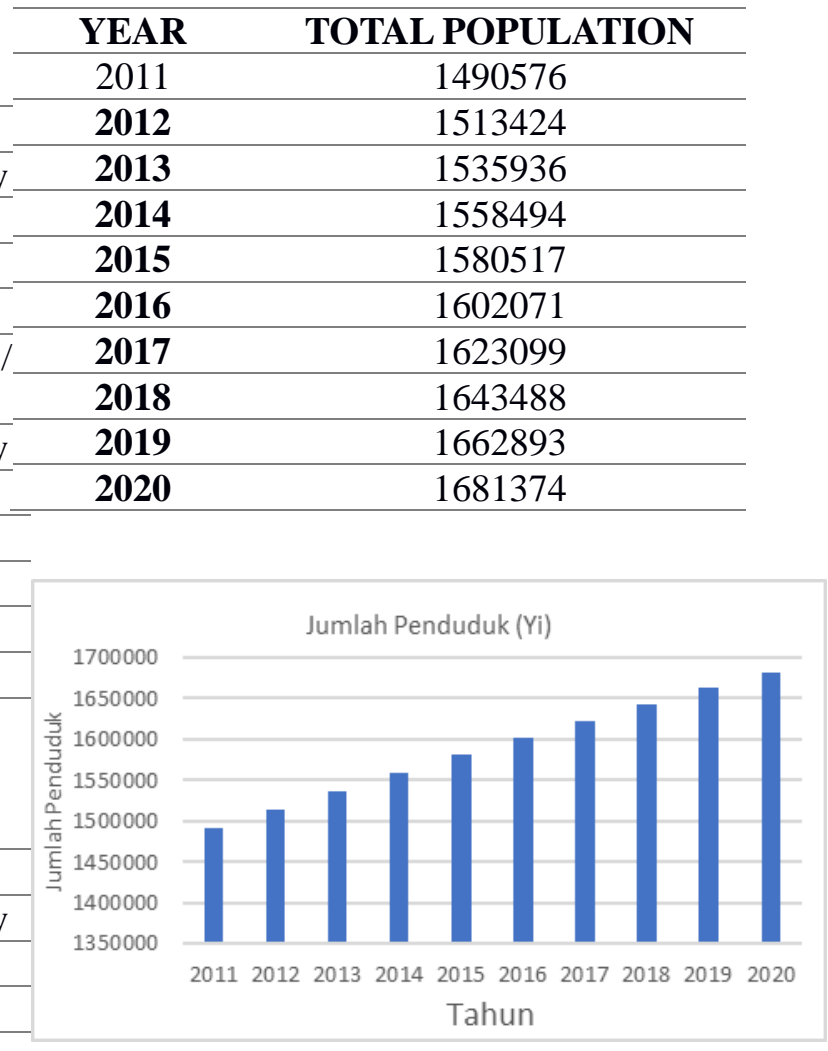

Figure 1. Total Population of Palembang City, 20112020

From the data above, it can be seen that there is an increase in the population of Palembang City every year. So that the amount of water needs every year also increases. 
Prediction of the amount of water demand in the future is necessary to know the ratio between the availability of clean water and the need for clean water.

\section{Forecasting the Number of Population}

There are three population projection methods: Arithmetic Method, Geometry Method, and Method Least Square. The projection calculation method selected will be based on the results of the value of Standard Deviation (SD) and the correlation coefficient (r). The correlation coefficient value must be close to 1 , and the value of Standard Deviation (SD) is the smallest value chosen.

\section{a. Arithmetic Method}

The results of calculating the population projection of Palembang City using the Arithmetic Method are presented in the table below:

Table 6. Population Projection of Palembang City with Arithmetic Method

\begin{tabular}{ccc}
\hline YEAR & Xi & Pn \\
\hline $\mathbf{2 0 2 1}$ & 1 & 1702574 \\
\hline $\mathbf{2 0 2 2}$ & 2 & 1723774 \\
\hline $\mathbf{2 0 2 3}$ & 3 & 1744973 \\
\hline $\mathbf{2 0 2 4}$ & 4 & 1766173 \\
\hline $\mathbf{2 0 2 5}$ & 5 & 1787373 \\
\hline $\mathbf{2 0 2 6}$ & 6 & 1808573 \\
\hline $\mathbf{2 0 2 7}$ & 7 & 1829772 \\
\hline $\mathbf{2 0 2 8}$ & 8 & 1850972 \\
\hline $\mathbf{2 0 2 9}$ & 9 & 1872172 \\
\hline $\mathbf{2 0 3 0}$ & 10 & 1893372 \\
\hline
\end{tabular}

With the Arithmetic method, the Standard Deviation (SD) value is obtained of 4226.26 and a correlation coefficient (r) of 0.99 .

\section{b. Geometry Methods}

The results of calculating the population projection of Palembang City using the Geometry Method are presented in the table below:

Table 7. Population Projection of Palembang City with Geometry Method

\begin{tabular}{ccc}
\hline YEAR & Xi & Pn \\
\hline $\mathbf{2 0 2 1}$ & 1 & 1704027 \\
\hline
\end{tabular}

\begin{tabular}{ccc}
\hline YEAR & Xi & Pn \\
\hline $\mathbf{2 0 2 2}$ & 2 & 1726986 \\
\hline $\mathbf{2 0 2 3}$ & 3 & 1750254 \\
$\mathbf{2 0 2 4}$ & 4 & 1773835 \\
\hline $\mathbf{2 0 2 5}$ & 5 & 1797734 \\
\hline $\mathbf{2 0 2 6}$ & 6 & 1821956 \\
\hline $\mathbf{2 0 2 7}$ & 7 & 1846503 \\
\hline $\mathbf{2 0 2 8}$ & 8 & 1871381 \\
\hline $\mathbf{2 0 2 9}$ & 9 & 1896595 \\
\hline $\mathbf{2 0 3 0}$ & 10 & 1922148 \\
\hline
\end{tabular}

With the Geometry Method, the Standard Deviation (SD) value is 6440.05 and a correlation coefficient (r) of 0.99 .

\section{c. Least Square Method}

The results of calculating the population projection of Palembang City using the Least Square Method are presented in the table below:

Table 8. Projection of Population in Palembang City with Least Square Method

\begin{tabular}{ccc}
\hline YEAR & Xi & Pn \\
\hline $\mathbf{2 0 2 1}$ & 11 & 1706407 \\
\hline $\mathbf{2 0 2 2}$ & 13 & 1727720 \\
\hline $\mathbf{2 0 2 3}$ & 15 & 1749032 \\
\hline $\mathbf{2 0 2 4}$ & 17 & 1770345 \\
\hline $\mathbf{2 0 2 5}$ & 19 & 1791658 \\
\hline $\mathbf{2 0 2 6}$ & 21 & 1812970 \\
\hline $\mathbf{2 0 2 7}$ & 23 & 1834283 \\
\hline $\mathbf{2 0 2 8}$ & 25 & 1855596 \\
\hline $\mathbf{2 0 2 9}$ & 27 & 1876909 \\
\hline $\mathbf{2 0 3 0}$ & 29 & 1898221 \\
\hline
\end{tabular}

With the Least Square method, the standard deviation (SD) value is 2198.19, and the correlation coefficient (r) is 0.99 .

\section{Projection Method}

The choice of population growth projection method is based on the value of Standard Deviation (SD) and the correlation coefficient $(r)$. Considerations in choosing a strategy include:

1. Standard Deviation (SD) must be the smallest. The slight Standard Deviation (SD) value indicates that the data obtained from the projection is not much different from the original data.

2. The correlation coefficient (r) must be 1 or 1 or close to both. 
The recapitulation of the calculation results of the Standard Deviation value and the correlation coefficient (r) of the three methods above are presented in the table below:

Table 9. Comparison of Standard Deviation Value (SD) and Correlation Coefficient (r).

\begin{tabular}{lcc}
\hline METHOD & $\begin{array}{c}\text { CORRELATI } \\
\text { ON } \\
\text { COEFFICIE } \\
\text { NT }\end{array}$ & $\begin{array}{c}\text { DEVIATION } \\
\text { STANDARD }\end{array}$ \\
\hline Arithmetic & 0.999 & 4226.26 \\
\hline Geometry & 0.998 & 6440.05 \\
\hline Least Square & 0.999 & 2198.19 \\
\hline
\end{tabular}

From the comparison data of the Standard Deviation (SD) and Correlation Coefficient (r) values, the smallest SD value is obtained, namely the Method Least Square with a value of 2198.19 and an r-value of 0.999 (close to 1).

From the calculation of the population projection using the method, Least SquareIt is found that the estimated population of Palembang City in 2030 will reach 1,898,221 people. This population growth is quite significant compared to the data from observations in 2020, which was $1,681,374$ people.

\section{Area Facilities Projection}

The types of area facilities to be projected are:

\section{a. Educational Facilities}

The educational facilities that will be projected are based on the number of students in the educational facilities. The projected types of facilities are Kindergarten, SD / MI, SMP, SMA, and University.

\section{b. Worship Facilities}

The projected types of worship facilities are mosques, prayer rooms, churches, monasteries, and temples.

\section{c. Medical facility}

The projected types of health facilities are: hospital/polyclinic (number of beds), health center, pharmacy.

d. Industrial Facilities
The industrial facilities projected are based on the number of employees working in the industrial sector in Palembang City.

e. Public facilities

The projected types of public facilities are: offices and a sports building.

\section{f. Trade and Service Facilities}

The projected types of trade and service facilities are terminals, shops, markets (wide), restaurants (seats), hotels (beds), cinemas.

\section{Determination Of Domestic Water Needs}

\section{a. Determination of Domestic Water Needs}

The calculation of domestic water demand is calculated using standards from the Ministry of Public Works (PU), namely the Technical Guidelines for Planning the Technical Design of the Drinking Water Supply System (1998). Domestic water demand can be seen in the table below.

Table 10. Service Coverage for Domestic Needs 2021-2030

\begin{tabular}{cccc}
\hline Year & $\begin{array}{c}\text { amount } \\
\text { Population }\end{array}$ & \multicolumn{2}{c}{$\begin{array}{c}\text { Scope } \\
\text { Service }\end{array}$} \\
\cline { 3 - 4 } & & \multicolumn{2}{c}{ Soul } \\
\hline $\mathbf{2 0 2 1}$ & $1,706,407$ & 60 & $1,023,844$ \\
\hline $\mathbf{2 0 2 3}$ & $1,749,032$ & 65 & $1,136,871$ \\
\hline $\mathbf{2 0 2 5}$ & $1,791,658$ & 70 & $1,254,160$ \\
\hline 2028 & $1,855,596$ & 75 & $1,391,697$ \\
\hline 2030 & $1,898,221$ & 80 & $1,518,577$ \\
\hline
\end{tabular}

Table 11. Number of House Connections (SR) and Public Hydrant (HU) for Domestic Needs 2021-2030

\begin{tabular}{|c|c|c|c|c|c|}
\hline \multirow[t]{2}{*}{ Year } & \multirow{2}{*}{$\begin{array}{c}\text { amount } \\
\text { Populatio } \\
\text { n }\end{array}$} & \multicolumn{2}{|r|}{ SR } & \multicolumn{2}{|r|}{ HU } \\
\hline & & $\%$ & Soul & $\%$ & Soul \\
\hline 2021 & $1,706,407$ & 70 & $1,194,485$ & 30 & 511,922 \\
\hline 2023 & $1,749,032$ & 70 & $1,224,323$ & 30 & 524,710 \\
\hline 2025 & $1,791,658$ & 70 & $1,254,160$ & 30 & 537,497 \\
\hline 2028 & $1,855,596$ & 80 & $1,484,477$ & 20 & 371,119 \\
\hline 2030 & $1,898,221$ & 80 & $1,518,577$ & 20 & 379,644 \\
\hline \multicolumn{6}{|c|}{$\begin{array}{l}\text { Table 12. Water Req } \\
\text { Connections } 2021-2030\end{array}$} \\
\hline Year & $\begin{array}{c}\text { amount } \\
\text { Populatio } \\
\text { n } \\
\text { Served } \\
\text { (Soul) }\end{array}$ & & $\begin{array}{l}\text { Std } \\
\text { Water } \\
\text { nsumption } \\
\text { / o / day) }\end{array}$ & & $\begin{array}{l}\text { Needs } \\
\text { Water } \\
(\text { L / sec })\end{array}$ \\
\hline
\end{tabular}




\begin{tabular}{llll}
\hline $\mathbf{2 0 2 1}$ & $1,706,407$ & 190 & 3,753 \\
\hline $\mathbf{2 0 2 3}$ & $1,749,032$ & 190 & 3,846 \\
\hline $\mathbf{2 0 2 5}$ & $1,791,658$ & 190 & 3,940 \\
\hline $\mathbf{2 0 2 8}$ & $1,855,596$ & 190 & 4,081 \\
\hline $\mathbf{2 0 3 0}$ & $1,898,221$ & 190 & 4,174 \\
\hline
\end{tabular}

Table 13. Water Requirement for General Hydrant 2021-2030

\begin{tabular}{cccc}
\hline Year & $\begin{array}{c}\text { amount } \\
\text { Populatio } \\
\mathbf{n} \\
\text { Served } \\
\text { (Soul) }\end{array}$ & $\begin{array}{c}\text { Std } \\
\text { Water } \\
\text { Consumption } \\
\text { (L / o / day) }\end{array}$ & $\begin{array}{c}\text { Needs } \\
\text { Water } \\
\text { (L / sec) }\end{array}$ \\
\hline $\mathbf{2 0 2 1}$ & $1,706,407$ & 30 & 593 \\
\hline $\mathbf{2 0 2 3}$ & $1,749,032$ & 30 & 607 \\
\hline $\mathbf{2 0 2 5}$ & $1,791,658$ & 30 & 622 \\
\hline $\mathbf{2 0 2 8}$ & $1,855,596$ & 30 & 644 \\
\hline $\mathbf{2 0 3 0}$ & $1,898,221$ & 30 & 659 \\
\hline
\end{tabular}

\section{b. Determination of Non-Domestic Water} Needs

The calculation of non-domestic water needs is calculated based on the Ministry of Public Works standard, namely the standard of water needs for urban facilities.

\section{1) Educational Facilities}

The need for drinking water for education facilities is calculated based on the standards of the Directorate General of Human Settlements, Public Works, 1998. With the standard requirement of $10 \mathrm{~L} /$ Student/day. The need for drinking water for educational facilities shows in the table below:

Table 14. Total Need for Drinking Water for Educational Facilities

\begin{tabular}{cccc} 
No. & Year & $\begin{array}{c}\text { Standard } \\
\text { Needs } \\
\text { (L / student } / \\
\text { day) }\end{array}$ & $\begin{array}{c}\text { Total } \\
\text { Water Needs } \\
\text { (L / sec) }\end{array}$ \\
\hline $\mathbf{1}$ & 2023 & 10 & 59.5 \\
\hline $\mathbf{2}$ & 2028 & 10 & 63.1 \\
\hline $\mathbf{3}$ & 2030 & 10 & 64.6 \\
\hline
\end{tabular}

\section{2) Worship Facilities}

The need for drinking water for worship facilities is calculated based on the standards of the Ministry of Public Works, 1996. The standard needs for mosques are 3000 (L / Unit / Day), 500 Mushola (L / Unit / Day), 300 Church (L / Unit / Day), Vihara 100 (L / Unit / Day) and Pura 100 (L / Unit / Day). The need for drinking water for worship facilities shows in the table below:
Table 15. Total Needs for Drinking Water for Worship Facilities

\begin{tabular}{|c|c|c|}
\hline $\begin{array}{l}\mathbf{N} \\
\text { o. }\end{array}$ & Year & $\begin{array}{c}\text { Total Water Requirements } \\
\text { (Mosques, prayer rooms, churches, } \\
\text { temples \& temples) } \\
(\mathrm{L} / \mathrm{sec})\end{array}$ \\
\hline 1 & 2023 & 35.2 \\
\hline 2 & 2028 & 35.3 \\
\hline 3 & 2030 & 35.3 \\
\hline
\end{tabular}

\section{3) Health Facilities}

The need for drinking water for health facilities is calculated based on the standards of the Department of Public Works, 1996. Standard Needs for Hospitals / Polyclinics are 200 (L / Unit / Day), Puskesmas 2000 (L / Unit / Day), Pharmacy 100 (L / Unit / Day). The need for drinking water in health facilities can be seen in the table below:

Table 16. Total Need for Drinking Water in Health Facilities

\begin{tabular}{|c|c|c|}
\hline $\begin{array}{l}\mathbf{N} \\
\text { o. }\end{array}$ & Year & $\begin{array}{c}\text { Total Water Requirements } \\
\text { (Hospital / Polyclinic, Puskesmas \& } \\
\text { Pharmacy) } \\
\text { (L/ sec) }\end{array}$ \\
\hline 1 & 2023 & 1.5 \\
\hline 2 & 2028 & 1.6 \\
\hline 3 & 2030 & 1.6 \\
\hline
\end{tabular}

\section{4) Industrial Facilities}

The need for drinking water for industrial facilities is calculated based on the Directorate General of Human Settlements, Public Works, 1998. With a standard requirement of $10 \mathrm{~L} /$ person/day. The amount of water demand for industrial facilities is calculated based on the population of Palembang City who works in the industrial sector; the increase in the number of employees is calculated based on the projected population of Palembang City. The need for drinking water for industrial facilities can be seen in the table below:

Table 17. Total Need for Drinking Water in Industrial Facilities

\begin{tabular}{cccc}
\hline No. & Year & $\begin{array}{c}\text { Standard } \\
\text { Needs } \\
(\mathbf{L} / \text { person / day })\end{array}$ & $\begin{array}{c}\text { Total } \\
\text { Water Needs } \\
(\mathbf{L} / \text { sec })\end{array}$ \\
\hline $\mathbf{1}$ & 2023 & 10 & 0.1 \\
\hline $\mathbf{2}$ & 2028 & 10 & 0.1 \\
\hline $\mathbf{3}$ & 2030 & 10 & 0.1 \\
\hline
\end{tabular}




\section{5) Public Facilities}

The need for drinking water for facilities general is calculated based on the standards of the Ministry of Public Works, 1996. Standard office needs are 10 (L / Employee / Day), and the Sports Building 2000 (L / Unit / Day). The need for drinking water for public facilities can be seen in the table below:

Table 18. Total Need for Drinking Water for Public Facilities

\begin{tabular}{ccc}
\hline $\begin{array}{l}\text { N } \\
\text { o. }\end{array}$ & Year & $\begin{array}{c}\text { Total Water Requirements } \\
\text { (Office, Gymnasium) } \\
\text { (L / sec) }\end{array}$ \\
\hline $\mathbf{1}$ & 2023 & 1.5 \\
\hline $\mathbf{2}$ & 2028 & 1.6 \\
\hline $\mathbf{3}$ & 2030 & 1.7 \\
\hline
\end{tabular}

\section{6) Trade and Service Facilities}

The need for drinking water for public facilities is calculated based on the standards of the Ministry of Public Works, 1996 and the Director-General of Human Settlements, Public Works, 1998. Standard Terminal Needs are 2000 (L / Unit / Day), 500 Shops (L / Unit / Day), Market 12000 ( L / Unit / Day), Restaurant 100 (L / Unit / Day), Hotel 150 (L / Unit / Day) and Cinema 2000 (L / Unit / Day). The need for drinking water for trade and service facilities can be seen in the table below:

Table 19. Total Need for Drinking Water for Trade and Service Facilities

\begin{tabular}{|c|c|c|}
\hline $\begin{array}{l}\mathbf{N} \\
\text { o. }\end{array}$ & Year & $\begin{array}{c}\text { Total Water Requirements } \\
\text { (Terminals, Shops, Markets, } \\
\text { Restaurants, Hotels, and Cinemas) } \\
\text { (L/ sec) }\end{array}$ \\
\hline $\mathbf{1}$ & 2023 & 299.3 \\
\hline 2 & 2028 & 304.3 \\
\hline 3 & 2030 & 306.2 \\
\hline
\end{tabular}

\section{Recapitulation Of Domestic And Non- Domestic Water Need}

The total amount of Domestic and NonDomestic Water needs in the planning area can be seen in the recapitulation table below:

Table 20. Total Domestic and Non-Domestic Water Needs

\begin{tabular}{ccccc}
\hline No. & Amenities & \multicolumn{3}{c}{ Requirement $(L /$ sec $)$} \\
\cline { 3 - 4 } & & 2023 & 2028 & 2030 \\
\hline 1 & Domestic & & & \\
\hline
\end{tabular}

\begin{tabular}{|c|c|c|c|c|}
\hline & Home Connection & 3,846 & 4,081 & 4,174 \\
\hline & General Hydrant & 607 & 644 & 659 \\
\hline & Amount (L / sec) & 4,454 & 4,725 & 4,833 \\
\hline \multirow[t]{9}{*}{2} & Non Domestic & & & \\
\hline & $\begin{array}{l}\text { Educational } \\
\text { Facilities }\end{array}$ & 59.51 & 63.13 & 64.58 \\
\hline & Worship Facilities & 35.18 & 35.27 & 35.27 \\
\hline & Medical facility & 1.52 & 1.57 & 1.58 \\
\hline & Industrial Facilities & 0.07 & 0.08 & 0.08 \\
\hline & Public facilities & 1.54 & 1.62 & 1.65 \\
\hline & $\begin{array}{l}\text { Trade \& Service } \\
\text { Facilities }\end{array}$ & 299.30 & 304.25 & 306.24 \\
\hline & Amount (L / sec) & 397.11 & 405.92 & 409.40 \\
\hline & tal Amount (L/ sec) & 4850.67 & 5130.82 & 5242.84 \\
\hline
\end{tabular}

\section{Loss of Water}

The total amount of water demand is the total amount of water demand minus water losses. The amount of water loss is estimated to be $20 \%$ of the total demand.

The amount of water loss from 20232030 can be seen in the table below:

Table 21. Water Loss

\begin{tabular}{cccc}
\hline Year & $\begin{array}{c}\mathbf{Q}(\mathbf{L} / \\
\text { sec })\end{array}$ & \% Lost & $\begin{array}{c}\mathbf{Q}(\mathbf{L} / \\
\text { sec })\end{array}$ \\
\hline 2023 & $4,850.67$ & 20 & 970.13 \\
\hline 2028 & $5,130.82$ & 20 & $1,026.16$ \\
\hline 2030 & $5,242.84$ & 20 & $1,048.57$ \\
\hline
\end{tabular}

\section{Total Water Need}

Total water demand is based on population projections, projections of domestic and non-domestic needs, as well as water losses, so it can be seen that the projected total water needs in 2023-2030 The total water requirement can be seen in the table below:

Table 22. Total Water Requirements

\begin{tabular}{ccccc}
\hline Year & $\begin{array}{c}\text { Q } \\
\text { Domestic } \\
\text { \& Non } \\
\text { Domestic } \\
\text { (L / sec) }\end{array}$ & $\begin{array}{c}\text { Q Fire } \\
\text { Hydrant } \\
(\mathbf{L} / \mathbf{s e c})\end{array}$ & $\begin{array}{c}\text { Q Lost } \\
\text { (L/ sec) }\end{array}$ & $\begin{array}{c}\text { Q } \\
\text { Total } \\
\text { (L / } \\
\text { sec) }\end{array}$ \\
\hline $\mathbf{2 0 2 3}$ & 4850.67 & 485.07 & 970.13 & 6,306 \\
\hline $\mathbf{2 0 2 8}$ & 5130.82 & 513.08 & $1,026.16$ & 6,670 \\
\hline $\mathbf{2 0 3 0}$ & 5242.84 & 524.28 & $1,048.57$ & 6,816 \\
\hline
\end{tabular}

\section{CONCLUSION}

The projection of the amount of water demand in Palembang City is calculated using statistical methods, namely the Arithmetic Method, the Geometry Method, and the Least Square Method. The data obtained from the 
Central Bureau of Statistics are calculated using these three methods, of which the method chosen is the Least Square method. This is based on the correlation coefficient results, which is 1 or close to one and with the smallest Standard Deviation value. The calculation shows that the increase in the population of Palembang City in 2030 will increase by $1,898,221$ people. So that with the projection of the people in 2030, the amount of domestic water demand can be obtained, namely 4,833 L/ second in 2030.

Meanwhile, the amount of non-domestic water needs is obtained from the calculation of area facilities, namely: educational facilities, religious facilities, health facilities, industrial facilities, public facilities as well as trade and service facilities. The total non-domestic water demand in 2030 from the calculation of regional facilities is $409.4 \mathrm{~L}$ / second.

In addition, the amount of domestic and non-domestic water needs, to obtain the total demand, the amount of water loss is also calculated, the amount of water loss is as much as $20 \%$ of the total need. The calculation result of water loss in 2030 is $1,048.57 \mathrm{~L} /$ second.

Water demand for Palembang City in 2030 from the calculation of domestic, nondomestic, water needs. Fire Hydrant and the amount of water loss is $6,816 \mathrm{~L} / \mathrm{s}$.

\section{REFERENCES}

Afrianto, L. (2015). Proyeksi Kebutuhan Air Bersih Penduduk Kecamatan Indramayu Kabupaten Indramayu Sampai Tahun 2035. Universitas Pendidikan Indonesia, 1102794.

Deny. (2010). Evaluasi Jaringan Pipa Distribusi Air Bersih PDAM Kab. Kampar. Jurnal Perencanaan Wilayah
Dan Kota.

Heru Setiawan. (2014). Pencemaran Logam

Berat Di Perairan Pesisir Kota Makassar Dan Upaya Penanggulangannya. Info Teknis EBONI, 11(1), 1-13.

Juni, V. N., \& Tujuan, M. (2018). Air Bersih, Kebutuhan Air Bersih, Kapasitas Alat, Kapasitas Produksi, Standar Debit Minimum . 6, 79-84.

Kospa, H. S. D., \& Rahmadi, R. (2019). Pengaruh Perilaku Masyarakat Terhadap Kualitas Air di Sungai Sekanak Kota Palembang. Jurnal Ilmu Lingkungan, 17(2), 212. https://doi.org/10.14710/jil.17.2.212-221

Langi, B. V., \& Mangangka, I. R. (2015). Perencanaan Pengembangan Sistem Penyediaan Air Bersih Kelurahan Kayawu Kota Tomohon. 3(5), 303-312.

Nugraha Sadeli Utama. (2019). Proyeksi Kebutuhan Air Baku Kota Tasikmalaya Pada Tahun 2025. Jurnal Infrastruktur, 3(2), 137-145. https://doi.org/10.35814/infrastruktur.v3i2 .717

Suheri, A., Kusmana, C., Purwanto, M. Y. J., \& Setiawan, Y. (2019). Model Prediksi Kebutuhan Air Bersih Berdasarkan Jumlah Penduduk di Kawasan Perkotaan Sentul City. Jurnal Teknik Sipil Dan Lingkungan, 4(3), 207-218. https://doi.org/10.29244/jsil.4.3.207-218

Suriawiria, U. (1996). Air dalam kehidupan dan lingkungan yang sehat.

Suryani, A. S. (2016). Persepsi Masyarakat Dalam Pemanfaatan Air Bersih ( Studi Kasus Masyarakat Pinggir Sungai Di Palembang ). Aspirasi, 7(1), 33-48. 